\title{
Spatial extent of new particle formation events over the Mediterranean Basin from multiple ground-based and airborne measurements
}

\author{
Kevin Berland ${ }^{1}$, Clémence Rose ${ }^{1}$, Jorge Pey ${ }^{2}$, Anais Culot $^{1}$, Evelyn Freney ${ }^{1}$, Nikolaos Kalivitis ${ }^{3}$, \\ Giorgios Kouvarakis ${ }^{3}$, José Carlos Cerro ${ }^{4}$, Marc Mallet ${ }^{7}$, Karine Sartelet ${ }^{5}$, Matthias Beckmann ${ }^{6}$, Thierry Bourriane ${ }^{7}$, \\ Greg Roberts $^{7}$, Nicolas Marchand ${ }^{2}$, Nikolaos Mihalopoulos ${ }^{3,8}$, and Karine Sellegri ${ }^{1}$ \\ ${ }^{1}$ Laboratoire de Météorologie Physique, CNRS UMR 6016, Université Blaise Pascal, Aubière, France \\ ${ }^{2}$ Aix-Marseille Université, CNRS, LCE, UMR 7376, 13331, Marseille, France \\ ${ }^{3}$ Environmental Chemical Processes Laboratory, University of Crete, Heraklion, Crete, 71003, Greece \\ ${ }^{4}$ Laboratory of Environmental Analytical Chemistry, Illes Balears University, Palma, 07122, Spain \\ ${ }^{5}$ CEREA, joint laboratory Ecole des Ponts ParisTech - EDF R\&D, Université Paris-Est, 77455 Champs sur Marne, France \\ ${ }^{6}$ Laboratoire Interuniversitaire des Systèmes Atmosphériques (LISA), UMR-CNRS 7583, Université Paris-Est-Créteil \\ (UPEC) et Université Paris Diderot (UPD), Institut Pierre Simon Laplace (IPSL), Créteil, France \\ ${ }^{7}$ Centre National de Recherches Météorologiques, Météo-France, Toulouse, URA1357, France \\ ${ }^{8}$ IERSD, National Observatory of Athens, P. Penteli, 15236, Athens, Greece \\ Correspondence to: Karine Sellegri (k.sellegri@opgc.univ-bpclermont.fr)
}

Received: 18 October 2016 - Discussion started: 12 December 2016

Revised: 1 June 2017 - Accepted: 14 June 2017 - Published: 9 August 2017

\begin{abstract}
Over the last two decades, new particle formation (NPF), i.e., the formation of new particle clusters from gas-phase compounds followed by their growth to the 10$50 \mathrm{~nm}$ size range, has been extensively observed in the atmosphere at a given location, but their spatial extent has rarely been assessed. In this work, we use aerosol size distribution measurements performed simultaneously at Ersa (Corsica) and Finokalia (Crete) over a 1-year period to analyze the occurrence of NPF events in the Mediterranean area. The geographical location of these two sites, as well as the extended sampling period, allows us to assess the spatial and temporal variability in atmospheric nucleation at a regional scale. Finokalia and Ersa show similar seasonalities in the monthly average nucleation frequencies, growth rates, and nucleation rates, although the two stations are located more than $1000 \mathrm{~km}$ away from each other. Within this extended period, aerosol size distribution measurements were performed during an intensive campaign (3 July to 12 August 2013) from a ground-based station on the island of Mallorca, as well as onboard the ATR-42 research aircraft. This unique combination of stationary and mobile measurements provides us with detailed insights into the horizontal and verti-
\end{abstract}

cal development of the NPF process on a daily scale. During the intensive campaign, nucleation events occurred simultaneously both at Ersa and Mallorca over delimited time slots of several days, but different features were observed at Finokalia. The results show that the spatial extent of the NPF events over the Mediterranean Sea might be as large as several hundreds of kilometers, mainly determined by synoptic conditions. Airborne measurements gave additional information regarding the origin of the clusters detected above the sea. The selected cases depicted contrasting situations, with clusters formed in the marine boundary layer or initially nucleated above the continent or in the free troposphere (FT) and further transported above the sea.

\section{Introduction}

New particle formation (NPF) events have been widely observed in the atmosphere in different environments (Kulmala et al., 2004) from remote areas at high altitude or latitude to polluted environments in different climates (Pey et al., 
2008; Manninen et al., 2010; Yli-Juuti et al., 2011; Cusack et al., 2013). However, the exact mechanism and chemical species involved in the NPF process are not fully identified, especially regarding the diversity of environments to consider. Thus, most global climate models still do not represent this process well, and they use parameterizations which are based upon a limited number of mechanisms and gaseous precursors, even though they predict that it may contribute to a significant fraction of condensation nuclei $(\mathrm{CN})$ and cloud condensation nuclei $(\mathrm{CCN})$ concentration at the global scale (Spracklen et al., 2008; Merikanto et al., 2009; Makkonen et al., 2012).

The different features of NPF events (frequency, intensity, duration) may be influenced not only by meteorological variables (temperature, relative humidity, and solar radiation) (Birmili et al., 2003; Jeong et al., 2004; Sihto et al., 2006; Young et al., 2007) but also by the availability of gaseous precursors, regarding both their nature and their amount. It is thus necessary to describe the occurrence and characteristics of NPF over a large variety of environments and assess to what spatial extent these features can be applied. Although the characteristics of the NPF events have often been documented in the literature (Hirsikko et al., 2007; Manninen et al., 2010; Yli-Juuti et al., 2009, 2011), analyses dedicated to their spatial extent are rarer. This might be explained by the fact that such studies require airborne measurements (Crumeyrolle et al., 2010; Rose et al., 2015a) or multi-site datasets. Such datasets have been analyzed by Vana et al. (2004) and Hussein et al. (2009), who reported that NPF could take place in the form of regional events over up to a thousand kilometers in Scandinavia, and at least $500 \mathrm{~km}$ over the western coast of South Korea (Kim et al., 2016). Likewise, Dall'Osto et al. (2013) observed regional NPF events occurring in the northeast of Spain. Using a similar methodology, Crippa and Pryor (2013) observed horizontal extents of a hundred kilometers for the NPF process in USA and Canada. They also pointed out a significant variability in the NPF characteristics (formation and growth rates) within these large-scale events, suggesting that local influences could add to favorable synoptic conditions. In order to allow for the analysis of the horizontal extent of NPF on a single-station dataset, different methods based on air mass back-trajectory analysis and particle growth rates have also recently been proposed (Kristensson et al., 2014; Rose et al., 2015b). The Nanomap tool developed by Kristensson et al. (2014) was reported to allow the identification of nucleation areas up to $500 \mathrm{~km}$ away from the observation site. The main limitation of this last method is due to the fact that the determination of the nucleation area directly depends on event characteristics that sometimes cannot be accurately defined (i.e., the determination of the end of the nucleation process itself, or the end of the growth process).

These studies dedicated to the analysis of the horizontal extent of NPF were mainly conducted above continental regions. Similar analyses in marine environments are crucially missing although they are of high interest, as it has previously been shown that, in such pristine environments, cloud properties could be significantly impacted by changes in the aerosol loading (Tao et al., 2012; Koren et al., 2014; Rosenfeld et al., 2014). Although the Mediterranean area is particularly sensitive to the future evolution of atmospheric pollutants and climate change, only a few studies related to NPF in this area have been reported so far. Intensive campaigns were conducted on the eastern Spanish coast, in Barcelona and at the Montseny site (Pey et al., 2008; Cusack et al., 2013), while long-term measurements are performed at the Finokalia (Crete) station (Kalivitis et al., 2008, 2012, 2015; Manninen et al., 2010; Pikridas et al., 2012), where NPF event days are close to $30 \%$. The Mediterranean Basin is at the cross section of many different influences: there is a strong anthropogenic influence from densely populated coastal zones, in addition to marine and dust sources, as well as with emissions from Mediterranean forests and shrublands that emit both terpenes and isoprene. This geographical area is particularly exposed to high solar radiation compared to the rest of Europe; thus, we expect a strong contribution from photochemical processes.

In the framework of the projects CHARMEX-ADRIMED (Mallet et al., 2016) and CHARMEX-SafMed, a large coordinated effort has been recently conducted to better characterize the physicochemical properties of the Mediterranean atmosphere. Measurements were conducted at ground stations on Mediterranean islands, such as Crete (Finokalia) and Corsica (Ersa) for an extended period of the years 20132014 and Mallorca (Cap d'Es Pinar) for several weeks during 2013. Forty research flights were also performed during the summers of 2013 and 2014. This vast dataset gave us a unique opportunity to characterize the spatial extent of the NPF process in the Mediterranean Basin. In this paper, we first report the long-term analysis of NPF event characteristics observed at Ersa (from May 2012 to August 2013) and Finokalia (from January to December 2013) using size distribution measurements in order to assess the large-scale space and time variability in NPF. We then focus our study on the special operation period (SOP) that took place during summer 2013. During this SOP additional measurements were performed in Mallorca (from 3 July to 12 August 2013) and aerosol particle size distributions and concentrations were measured onboard the ATR-42, which allowed for a deeper analysis of the horizontal and vertical development of the NPF process at daily scale.

\section{Experimental platforms, material, and methods}

\subsection{Ground-based measurements}

Ground-based aerosol measurements reported in this work were performed at the Finokalia station (Crete) from January to December 2013, at the Ersa station (Corsica) from 


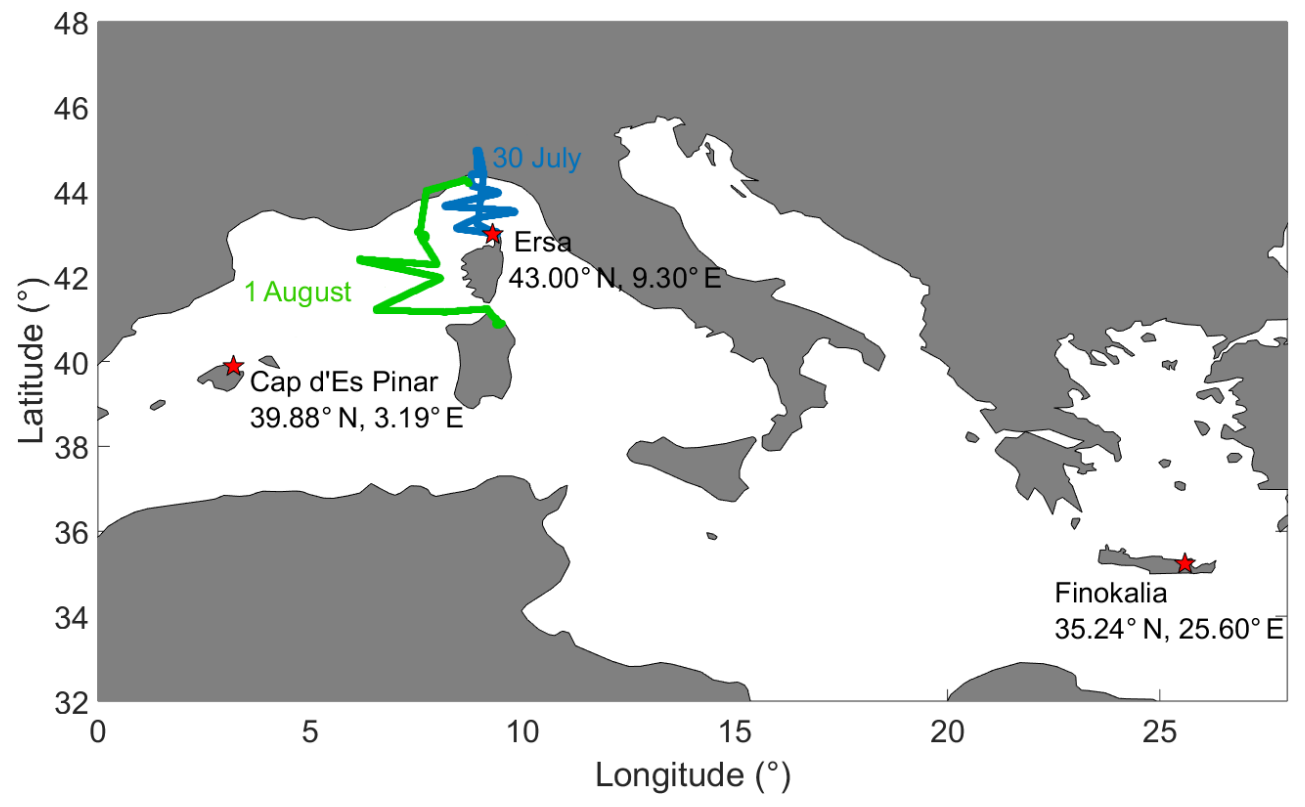

Figure 1. Locations of the stations: Ersa (Corsica), Finokalia (Crete), and Cap d'Es Pinar (Mallorca). Aircraft flight paths from 30 July and 1 August are also shown.

May 2012 to August 2013, and at the Cap d'Es Pinar station (Mallorca) from 3 July to 12 August 2013 (Fig. 1). Within these measurements periods, some gaps occurred in the Finokalia dataset (from 5 September to 15 October 2013) due to participation of the instrument in the ACTRIS (Aerosol Clouds and Trace gases Research Infrastructure) network mobility particle size spectrometer workshop, and in the Ersa dataset (from 1 September to 31 October 2012) because of instrumental failures.

The Finokalia station $\left(35.24^{\circ} \mathrm{N}, 25.60^{\circ} \mathrm{E}\right)$ is located on the northern coast of Crete, Greece, at the top of a hill ( 230 ma.s.1.) facing the sea. There is no significant human activity within an area of approximately $15 \mathrm{~km}$ around the station, mainly characterized by scarce vegetation (Mihalopoulos et al., 1997). The closest large urban area is the city of Heraklion, with 150000 inhabitants, located $50 \mathrm{~km}$ west of Finokalia. Aerosols at the site are mainly transported from southeastern Europe and northern Africa, and to a lesser extent from central and western Europe (Kouvarakis et al., 2000; Sciare et al., 2008; Pikridas et al., 2010, 2012). At Finokalia, aerosol particle size distributions were measured in the size range $9-849 \mathrm{~nm}$ with a time resolution of $300 \mathrm{~s}$ with a custom-made scanning mobility particle sizer (SMPS) (Wiedensohler et al., 2012). As previously described by Kalivitis et al. (2015), the system operates with a closedloop sheath air flow with a 5:1 ratio between the sheath and the aerosol flow. It comprises a $\mathrm{Kr}-85$ aerosol neutralizer (TSI 3077), a Hauke medium differential mobility analyzer (DMA), and a TSI-3772 condensation particle counter (CPC). The system is operated following the recommendations of Wiedensohler et al. (2012), thus meeting the Euro- pean infrastructure ACTRIS project requirements for quality insurance.

The Ersa station is located on the northern tip of the island of Corsica, at Cape Corsica (43.00 N, 9.30 $\mathrm{E}$; $530 \mathrm{~m}$ a.s.1.). On this part of the island the wind can be very strong, with frequent windstorms (78 days in 2007 with wind speeds stronger than $28 \mathrm{~m} \mathrm{~s}^{-1}$ ). Climate in Corsica is characterized by moist winters and dry summers, with less than 100 rainy days per year (Lambert et al., 2011). Aerosols reaching the site are of variable types, including mineral dust particles from north Africa; anthropogenic and biomass burning aerosols mainly originating from densely populated coastal areas located in eastern Spain, France, and Italy; and marine aerosols, from the Mediterranean Sea itself but also from the Atlantic Ocean (Nabat et al., 2013; Mallet et al., 2016). The Cape Corsica peninsula is a remote site, excluding important local anthropogenic sources that could affect the in situ measurements, and surrounded by scarce Mediterranean vegetation (Mallet et al., 2016). At Ersa, aerosol size distributions were measured with a scanning mobility particle sizer (SMPS TSI 3080, associated with a CPC TSI 3010) in the size range $10-495 \mathrm{~nm}$ with a time resolution of $300 \mathrm{~s}$.

The Cap d'es Pinar station is located on the northeastern side of the island of Mallorca $\left(39.88^{\circ} \mathrm{N}, 3.19^{\circ} \mathrm{E} ; 20 \mathrm{~m}\right.$ a.s.1.), on a peninsula between the Alcudia and Pollença bays. The station was established in one of the buildings belonging to the Spanish Ministry of Defense in its Cap d'Es Pinar facilities. The area is densely forested by Mediterranean shrublands and pine trees and the access to the station is restricted. Urban centers, the Alcudia and Pollença harbors, and main roads are located at least $10 \mathrm{~km}$ from the site. Particle size 
distributions were measured in the size range $15-600 \mathrm{~nm}$ with a time resolution of $300 \mathrm{~s}$ using a TSI SMPS, with a 3081 long DMA and a CPC TSI 3776.

\subsection{Airborne measurements}

Airborne measurements were carried out onboard the ATR42 French research aircraft operated by SAFIRE (Service des Avions Français Instrumentés pour la Recherche en Environnement). Figure 1 shows the aircraft trajectory during the flights performed on 30 July and 1 August, which are investigated in the next sections of the present work. The aerosol size distribution in the $20-485 \mathrm{~nm}$ diameter range was measured with a time resolution of $130 \mathrm{~s}$ using the SMPS system previously described in Crumeyrolle et al. (2010), which includes a CPC TSI 3010, a differential mobility analyzer (DMA) and a krypton aerosol neutralizer. The total concentrations of aerosols larger than $10 \mathrm{~nm}\left(N_{10}\right)$ and larger than $3 \mathrm{~nm}\left(N_{3}\right)$ were measured using a custom-made CPC dedicated to aircraft measurements (Weigel et al., 2009) and a CPC TSI 3025, respectively. The concentration of particles in the size range $3-10 \mathrm{~nm}\left(N_{3-10}\right)$ was calculated as the difference between $N_{3}$ and $N_{10}$. After analysis of the variability in $N_{3-10}$ apart from nucleation periods, we found that $N_{3-10}$ concentrations are above the variability in the two CPC concentration difference when exceeding the threshold of $395 \mathrm{~cm}^{-3}$. For more details on the airborne instrumentation and data analysis procedure, the reader is referred to Rose et al. (2015a).

\section{Data analysis}

\subsection{NPF event classification}

From ground-based observations, measurement days were classified according to Dal Maso et al. (2005) into four categories: events days, including classes I and II; undefined; and non-events days. Class I events are characterized by a strong increase in sub- $25 \mathrm{~nm}$ particles concentrations, their persistence over a period of more than an hour, and a clear growth of the nucleation-mode particles towards larger sizes during the following hours. Class II events have the same characteristics as Class I events, except that they may be less intense or show a discontinuity in the growth of the clusters. Days are considered undefined when the newly observed particles are detected only from the Aitken size and/or when they do not grow during the course of the day.

\subsection{Particle formation and growth rate calculations}

Particle formation and growth rates are key entities to assess the strength of events belonging to Class I and II. While formation rates $(J)$ are usually calculated for $10 \mathrm{~nm}$ particles $\left(J_{10}\right)$, sampling line issues causing high variability in the sub-16nm concentrations in Cap d'Es Pinar (see Fig. 7) only allowed for calculations involving larger diameter particle concentrations $\left(J_{16}\right)$. In order to ease the comparison between Ersa and Cap d'Es Pinar, a similar size range was applied for $J$ calculation from the Ersa dataset. For comparison with the literature, one has to keep in mind that $J_{16}$ are lower than $J_{10}$, due to coagulation effects during the growth of the particles from 10 to $16 \mathrm{~nm}$.

Growth rates (GRs) were calculated from the SMPS nucleation-mode concentrations (16-20 nm) using the "maximum" method from Hirsikko et al. (2005). The time corresponding to the maximum concentration was first determined for each of the SMPS size channels in the range $16-20 \mathrm{~nm}$ by fitting a normal distribution to the concentration. The growth rate was then derived from a linear least squares fit through these time values.

From this growth rate, we derived the total particle formation rate at $16 \mathrm{~nm}\left(J_{16}\right)$, similar to Dal Maso et al. (2005), using the following equation (Eq. 1):

$J_{16}=\frac{\mathrm{d} N_{16}}{\mathrm{~d} t}+\operatorname{CoagS}_{16} \cdot N_{16}+\frac{\mathrm{GR}_{16-20}}{(20-16) \mathrm{nm}} \cdot N_{16}$.

CoagS $_{16}$ is the coagulation sink of $16 \mathrm{~nm}$ particles on larger particles, $N_{16}$ is the total concentration of $16-20 \mathrm{~nm}$ particles and $\mathrm{GR}_{16-20}$ is the growth rate corresponding to the same diameter range.

\section{Results and discussion}

\subsection{Yearly statistical analysis of NPF event characteristics at two ground-based stations}

The goal of this first section is to provide an overview of the seasonal variability in NPF in the Mediterranean area, and some insights into the spatial homogeneity of the NPF occurrence over the basin.

\subsubsection{NPF event frequency and types}

The yearly average NPF frequencies, calculated as the number of event days over the total number of measurement days, are very similar at Finokalia and Ersa, being 36\% (109 events) and $35 \%$ (96 events), respectively (Table 1). A comparable value was reported by Pikridas et al. (2012) at Finokalia, with a yearly average frequency of $\sim 33 \%$ calculated over a year from April 2008 to April 2009. At both stations, the NPF frequency shows a clear annual cycle, with the highest frequencies observed during spring ( $52 \%$ in May for Finokalia and $56 \%$ in April for Ersa) and the lowest in autumn (Fig. 2). A similar seasonal variation was previously reported for Finokalia, with a slight time offset of the NPF frequency peak observed in February-March (Pikridas et al., 2012). More generally, higher NPF frequencies are frequently observed during spring (April-May-June) compared to the rest of the year at European stations (Manninen et al., 2010). As previously suggested by Manninen et al. (2010, 
Table 1. Classification of measurement days in Ersa and Finokalia (after filtering bad data).

\begin{tabular}{|c|c|c|c|c|c|}
\hline & \multirow{2}{*}{$\begin{array}{l}\text { Number of } \\
\text { measurements } \\
\text { days }\end{array}$} & \multicolumn{2}{|c|}{$\begin{array}{l}\text { Event } \\
\text { days }\end{array}$} & \multirow[t]{2}{*}{$\begin{array}{c}\text { Undefined } \\
\text { days }\end{array}$} & \multirow[t]{2}{*}{$\begin{array}{l}\text { Non-event } \\
\text { days }\end{array}$} \\
\hline & & Type I & Type II & & \\
\hline Ersa & 276 & 43 & 53 & 23 & 157 \\
\hline Finokalia & 301 & 38 & 71 & 27 & 165 \\
\hline
\end{tabular}

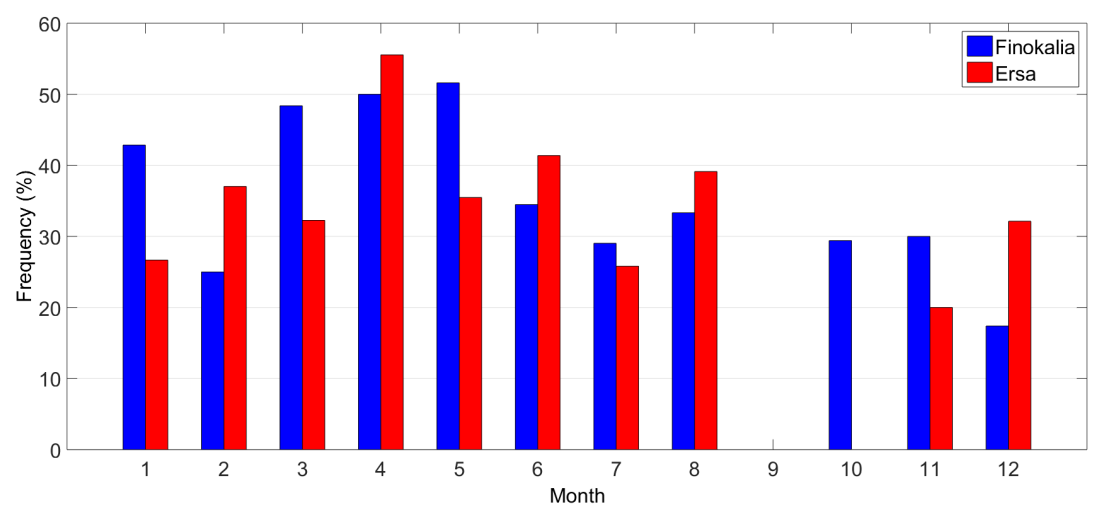

Figure 2. Monthly mean NPF frequencies at Finokalia and Ersa.
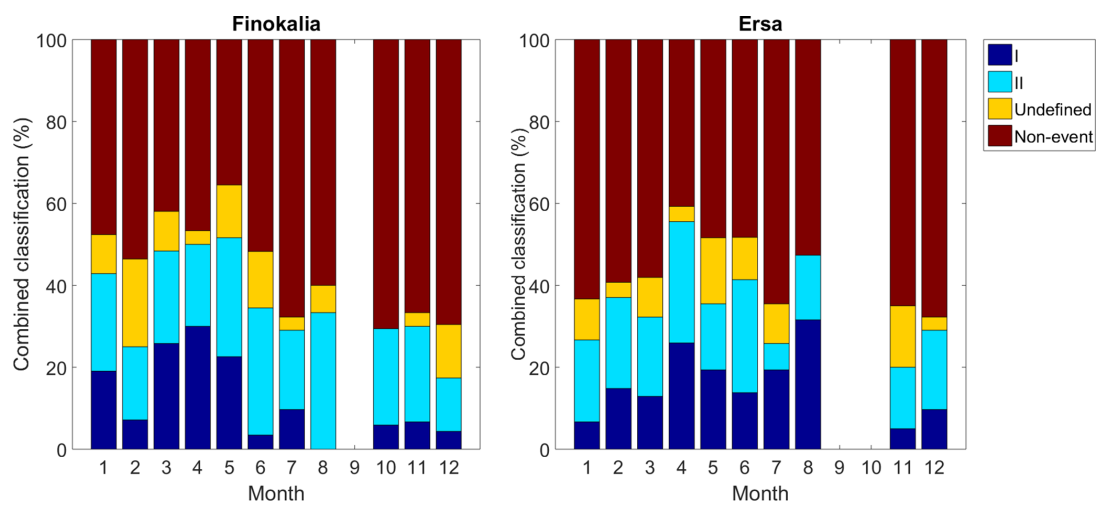

Figure 3. Monthly classification of the measurement days into event (I and II), undefined, and non-event categories in Finokalia and Ersa.

and references therein) and further supported by Fig. S1 in the Supplement, higher NPF frequencies in spring are most probably related to the onset of biogenic emissions, which is favored by increasing temperatures, together with higher solar radiation enhancing the production of low-volatility oxidized vapors.

The classification of the event days into the different categories (Fig. 3 and Table 1) shows that the occurrence of type I events in Finokalia follows the same seasonal variation as the total NPF frequency, being maximum during the spring season (up to $26 \%$ of all days). This indicates that spring is favorable to both formation of new particles and their growth to larger sizes. Type II events are annually the most frequent, representing between 13 and $31 \%$ of all measurement days with no clear seasonal variation. In contrast, undefined days are not frequently observed in Finokalia, around $9 \%$ on average. Very similar features are observed in Ersa: type I events show the highest frequency of occurrence during spring and summer (up to $32 \%$ of all days in August), while they represent less than $10 \%$ of the measurement days during winter. The frequency of occurrence of type II events is on average $19 \%$, with no clear seasonal variation.

\subsubsection{Growth rates and particle formation rates}

Particle formation and growth rates were calculated for type I events in order to characterize the strength of the events observed at the two stations. The yearly median particle 
Table 2. Annual median formation rates, growth rates, and annual CS in Ersa and Finokalia. Percentiles are also reported as additional information.

\begin{tabular}{|c|c|c|c|c|c|c|c|c|c|}
\hline & \multicolumn{3}{|c|}{$J_{16}\left(\mathrm{~cm}^{-3} \mathrm{~s}^{-1}\right)$} & \multicolumn{3}{|c|}{$\mathrm{GR}_{16-20}\left(\mathrm{nmh}^{-1}\right)$} & \multicolumn{3}{|c|}{$\mathrm{CS}\left(\mathrm{s}^{-1}\right)$} \\
\hline & 25 th perc. & Med. & 75th perc. & 25 th perc. & Med. & 75th perc. & 25 th perc. & Med. & 75th perc. \\
\hline Ersa & $1.4 \times 10^{-1}$ & $1.6 \times 10^{-1}$ & $3.0 \times 10^{-1}$ & 6.6 & 7.1 & 12.2 & $3.3 \times 10^{-3}$ & $4.1 \times 10^{-3}$ & $4.6 \times 10^{-3}$ \\
\hline Finokalia & $1.9 \times 10^{-1}$ & $2.6 \times 10^{-1}$ & $2.8 \times 10^{-1}$ & 10.4 & 16.7 & 25.6 & $3.4 \times 10^{-3}$ & $6.2 \times 10^{-3}$ & $9.3 \times 10^{-3}$ \\
\hline
\end{tabular}

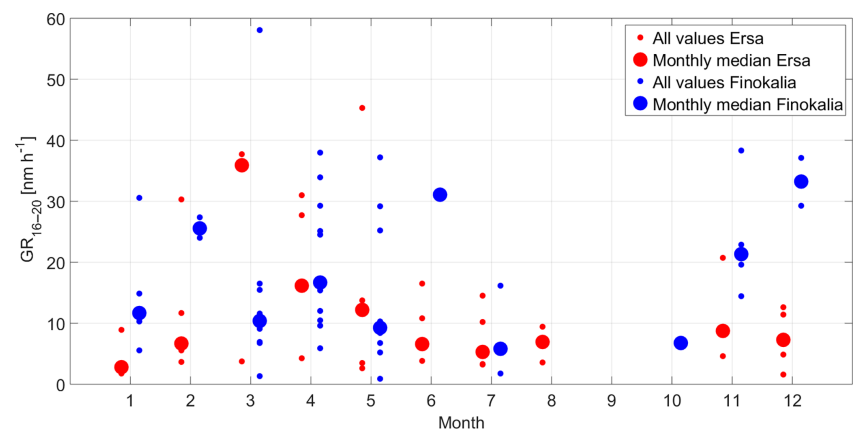

Figure 4. Annual variation of particle growth rate calculated for the range 16-20 nm at Ersa and for type I events. Small dots represent all values, while large dots stand for median values.

growth rates in the range $16-20 \mathrm{~nm}\left(\mathrm{GR}_{16-20}\right)$ are 7.10 and $16.7 \mathrm{nmh}^{-1}$ at Ersa and Finokalia, respectively (Table 2). The values obtained at Finokalia are in the upper range of the values reported by Manninen et al. (2010) at European sites for $7-20 \mathrm{~nm}$ diameter particles $\left(1.8-20 \mathrm{~nm} \mathrm{~h}^{-1}\right.$, mean value $4.4 \mathrm{~nm} \mathrm{~h}^{-1}$ ). In particular, the values calculated in this work are on average higher compared to those obtained at other European coastal sites such as Cabauw $\left(2.1-19 \mathrm{~nm} \mathrm{~h}^{-1}\right.$, mean value $\left.6.7 \mathrm{nmh}^{-1}\right)$ and Mace Head $\left(2.7-10 \mathrm{nmh}^{-1}\right.$, mean year value $5.4 \mathrm{~nm} \mathrm{~h}^{-1}$ ) (Manninen et al., 2010). Higher growth rates are expected in environments with high solar radiation and emissions, such as the Mediterranean Basin. However, the median value reported here is also higher than the one reported for Finokalia from the years 2008-2009 in the size range 7-20 $\mathrm{nm}\left(5 \mathrm{nmh}^{-1}\right)$ (Manninen et al., 2010). This result may be explained by the higher size range used here for the GR calculation (16-20 nm instead of 7-20 nm), which leads to not only higher values because GR usually increases with particle size but also higher uncertainty because of the narrow size range. Figure 4 displays the annual variation of the particle growth rates at Ersa and Finokalia. At Ersa, GRs have the same seasonal variation as the NPF frequency, with higher values in spring compared to the rest of the year. At Finokalia, the GR seasonality is not as clear as in Ersa. However, the seasonality in Finokalia is rather biased because there are only a few class I events during summer.

The yearly median particle formation rates $\left(J_{16}\right)$ are $0.16 \mathrm{~cm}^{-3} \mathrm{~s}^{-1}$ in Ersa and $0.26 \mathrm{~cm}^{-3} \mathrm{~s}^{-1}$ in Finokalia (Table 2). These values are slightly lower than the $J_{10}$ values

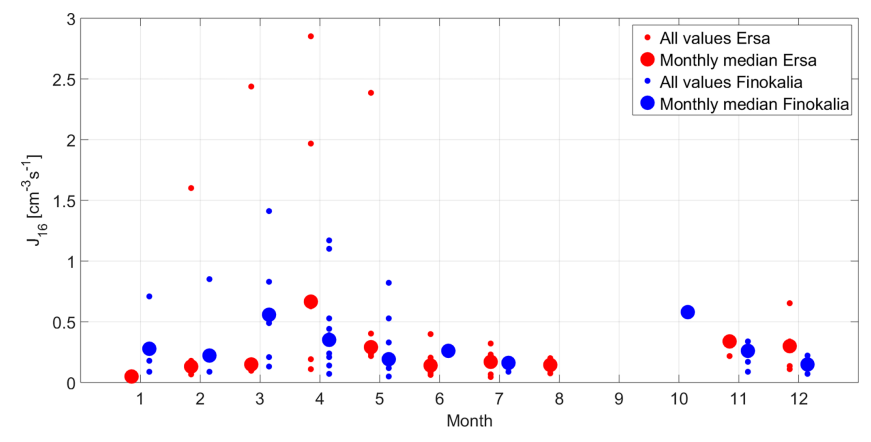

Figure 5. Annual variation of the $16 \mathrm{~nm}$ particle formation at Ersa and Finokalia for type I events. Small dots represent all values, while large dots stand for median values.

reported by Kulmala et al. (2004) from several coastal sites and ship campaigns conducted in the Baltic, Atlantic and Pacific areas $\left(0.4-1.5 \mathrm{~cm}^{-3} \mathrm{~s}^{-1}\right)$. Besides different environmental conditions which might explain these differences, one has to keep in mind that $J_{16}$ values are expected to be lower than $J_{10}$ because of the coagulation processes which cause particle loss during their growth. The values calculated in this work are, to our knowledge, the first reported for the formation of nucleation-mode particles $(10-20 \mathrm{~nm})$ in the Mediterranean Basin. As shown in Fig. 5, median $J_{16}$ also follows a seasonal variation similar to the NPF frequency at both stations, with higher values in spring (March, with $0.56 \mathrm{~cm}^{-3} \mathrm{~s}^{-1}$ for Finokalia, and April, with $0.66 \mathrm{~cm}^{-3} \mathrm{~s}^{-1}$ for Ersa). This observation suggests that condensable vapors needed to grow the clusters up to $16 \mathrm{~nm}$ are most likely of the same origin as those initiating the NPF process. In contrast, lower $J_{16}$ are observed in early winter and mid-summer at both stations.

It is worth noting that in Ersa, even though NPF frequencies are lower in autumn compared to spring, particle formation rates are comparable. This last observation suggests that, despite being less frequent, favorable conditions for NPF can be found during autumn and lead to events with the same intensity as in spring, when radiation and biogenic emissions are on average higher compared to the rest of the year (Manninen et al., 2010). The seasonal variation of nucleation frequency, nucleation rates, and growth rates is most likely related to the availability of condensable gases. The amount of such precursors results from the balance between a com- 
bination of emissions and radiation, which favor their production, and their loss onto preexisting particles. In order to assess the influence of the preexisting aerosol population on NPF, we calculated the condensational sink (CS) according to Pirjola et al. (1999). The CS was first derived from SMPS measurements for the whole measurement period at both stations and was finally averaged over the $2 \mathrm{~h}$ period prior to the onset of NPF events. On non-event days, the CS was averaged over the $2 \mathrm{~h}$ time period prior to the time at which NPF is triggered on event days, i.e., 11:00 UTC in Finokalia and $\sim$ 12:00 UTC in Ersa. The annual variation of the median CS derived from these averaged values is reported for event and non-event days in Fig. 6.

The CS has a strong seasonal cycle with a clear maximum during summer at both stations. This observation may explain the lower NPF frequencies, formation rates, and growth rates that are on average observed during this season, which otherwise shows high radiation (Fig. S1), and most probably high biogenic emissions. In addition, the CS is on average higher during non-event days at both stations. This confirms that the CS is likely a limiting factor for the occurrence of NPF at these stations. This has already been pointed out by Kulmala et al. (2005), Hamed et al. (2010), and Manninen et al. (2010) for several boundary layer stations in Europe, including both industrialized locations and more pristine areas, such as boreal forest. One should, however, note that during spring months (especially March and April), median CS is similar on event and non-event days. This observation suggests that, during this period, the strength of precursors emissions together with radiation might be driving the occurrence NPF to a major extent. Also, the CS is on average higher in Finokalia, especially during spring and summer, with monthly CS twice as high compared to Ersa. It is worth noting that large particles up to $848 \mathrm{~nm}$ are accounted for in the CS calculation in Finokalia, while the upper size limit is $495 \mathrm{~nm}$ in Ersa. However, particles above $500 \mathrm{~nm}$ only have a weak impact on the CS values due to their low concentration and thus do not explain the differences which are seen between the sites. At Finokalia, northnortheasterly winds dominate during summer, bringing high concentrations of anthropogenic aerosol that have aged when passing over the sea before reaching the station, thus leading to high CS values. The fact that NPF frequencies, nucleation rates and growth rates are comparable at the two stations indicates that the sources of condensable gases are likely to be significantly higher in Finokalia compared to Ersa in order to compensate for the large condensational sink measured at the Greek station.

Based on the previous observations, Finokalia and Ersa show similar seasonality in the average nucleation frequency, growth rates and nucleation rates although the two stations are more than $1000 \mathrm{~km}$ away from each other. It is worth mentioning that during the period of interest, 109 event days were observed at Finokalia and 96 at Ersa, among which 31 (with 8 events of class I) occurred at both stations at the same time. These results could indicate that the spatial extent of NPF events over the Mediterranean Basin is at the synoptic scale, and of the order of the distance between the two stations, i.e., more than $1000 \mathrm{~km}$. Such a conclusion has already been drawn from observations of NPF events at three stations located in northern Europe (Vana et al., 2004). However, we will downscale the comparison of occurrence and characteristics of events at the daily resolution (rather than monthly) in order to further investigate this hypothesis.

\subsection{Intensive campaign during summer 2013}

\subsubsection{Ground-based measurements - overview}

In this section, we focus on the special observation period (SOP) that took place from 3 June to 12 August in the frame of the CHARMEX project. During this period, number size distribution measurements were additionally conducted at the Mallorca station (Cap d'Es Pinar).

Figure 7 shows the SMPS particle size distributions recorded at the three ground-based stations during the SOP. From this synoptic overview, we clearly observe similar trends in the evolution of the particle size distributions in Ersa and Cap d'Es Pinar, with three distinct NPF periods during which NPF events occurred daily over several days (first period from 4 to 9 July, second period from 28 July to $3 \mathrm{Au}-$ gust, and third period from 9 to 12 August) (see Table S1 in the Supplement). This observation would confirm the spatial extent of NPF events at a large scale. However, these periods of intense NPF activity were not observed in Finokalia, where both the occurrence and strength of NPF events seem to be more homogeneous over the SOP. These contrasting observations might be explained by an environmental contrast between the eastern and western part of the Mediterranean Basin.

As reported in Table S1, during this 41-day period, NPF was observed to occur at one station (at least) on 23 days. Among these 23 event days, 8 events were observed on the same day on two stations at least. This frequency of simultaneous NPF events occurrence is very similar to the one observed at Korean coastal sites ( 5 out of 21 observation days, Kim et al., 2016). NPF was detected at all sites on $9 \mathrm{Au}-$ gust, and three events were reported on the same day for each of the station pairs Ersa-Finokalia and Ersa-Mallorca, and one event for the pair Finokalia-Mallorca. In order to further investigate the link that might exist between the events observed at the three stations, we first chose to focus our analysis on 3 days that belong to the three different NPF periods identified: 5 July, 29 July, and 9 August are presented as case studies. Type one events were observed in Ersa and Cap d'Es Pinar on those specific days, thus allowing for particle formation and growth rate calculations, and further direct comparison of event intensity at these two sites. 


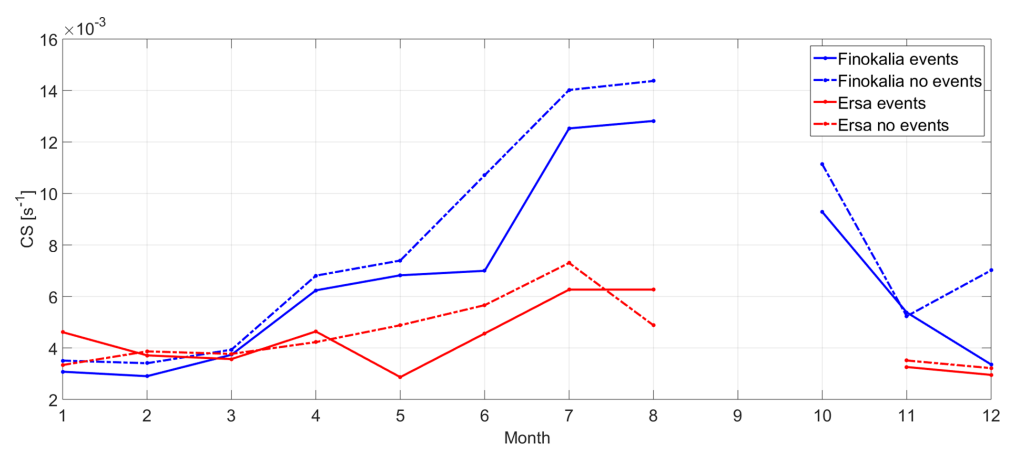

Figure 6. Median values of condensation sink (CS) reported separately for event and non-event days in Finokalia and Ersa.

Table 3. Average growth rates and formation rates computed for the three case studies at Ersa and Cap d'es Pinar.

\begin{tabular}{lrrrrr}
\hline & \multicolumn{2}{c}{ Ersa } & & \multicolumn{2}{c}{ Cap d'Es Pinar } \\
\cline { 2 - 3 } \cline { 6 - 7 } & \begin{tabular}{r}
$\mathrm{GR}_{15-25}\left(\mathrm{~nm} \mathrm{~h}^{-1}\right)$ \\
\cline { 6 - 7 }
\end{tabular} & $\begin{array}{r}\left.\mathrm{cm}^{-3} \mathrm{~s}^{-1}\right) \\
\text { 5 July }\end{array}$ & & $\begin{array}{r}\mathrm{GR}_{15-25} \\
\left(\mathrm{nmh}^{-1}\right)\end{array}$ & $\begin{array}{r}J_{20} \\
\left(\mathrm{~cm}^{-3} \mathrm{~s}^{-1}\right)\end{array}$ \\
29 July & 16.4 & $2.4 \times 10^{-1}$ & & 7.8 & $4.1 \times 10^{-2}$ \\
9 August & 8.9 & $7.9 \times 10^{-2}$ & & 4.8 & $7.8 \times 10^{-2}$ \\
\hline
\end{tabular}

\subsubsection{Ground-based measurements: case studies}

We calculated the total formation rate of $20 \mathrm{~nm}$ particles $\left(J_{20}\right)$ using particle growth rates in the size range $15-25 \mathrm{~nm}$ (GR ${ }_{15-25}$, Table 3$)$ for the three cases: 5 July, 29 July, and 9 August. We first shortly describe the NPF events observed on 5 and 29 July (fully described in the Supplement) and then illustrate in more detail the events observed on 9 August that have the most similarities between sites.

On 5 July, although NPF occurs both at Ersa and Cap d'Es Pinar, the time evolution of particle concentrations are very different from one site to the other. Particles of the smallest size range are detected in the morning at Ersa, but only later in the afternoon at Cap d'Es Pinar, and at larger sizes and lower concentrations (Fig. S2). The $24 \mathrm{~h}$ air mass back-trajectory analysis (HYSPLIT transport and dispersion model; Draxler et al., 2003) shows that air masses arriving at both stations are of northerly origin (Fig. S3). Hence, it is unlikely that particles formed during the NPF event detected at Ersa in the morning have been transported west and detected later in the afternoon at Cap d'es Pinar.

In order to further evaluate the spatial extent of nucleation, we estimated for each site the distance between the station the place where nucleation was initially triggered upstream of the station. The method we used is based on the time evolution of the aerosol size distribution and was previously described by Rose et al. (2015b). We assumed that $20 \mathrm{~nm}$ particles detected at the station were originally formed by NPF and that nucleated clusters had a diameter of $1 \mathrm{~nm}$.
The time required for a cluster to grow between 1 and $20 \mathrm{~nm}$ was first calculated using $\mathrm{GR}_{15-25}$. Then, knowing the time corresponding to the maximum concentration of $20 \mathrm{~nm}$ particles at the station, we were able to calculate the time at which nucleation occurred. Finally, using air mass back-trajectories we determined the location where nucleation had been triggered upstream of the station. It is worth noting that since particle growth rates were reported to increase with particle size (Yli-Juuti et al., 2011), GR $_{15-25}$ provide an underestimation of the particle growth time between 1 and $20 \mathrm{~nm}$, and therefore a lower limit of the distance between the place where nucleation is initially triggered and the station.

On 5 July, previous calculations led to distances of at least $9 \mathrm{~km}$ (Ersa) and $40 \mathrm{~km}$ (Cap d'Es Pinar) upstream of the stations, which thus does not allow for further conclusions to be made on the simultaneity of a large NPF covering the spatial area of both stations. The event of 29 July is detected from the lowest sizes of the SMPS at both stations with the same intensity (similar $N_{15-20}$ and $J_{20}$ ), showing similar features (Fig. S4), but is detected $1 \mathrm{~h}$ earlier at Cap d'Es Pinar than at Ersa. Air masses were from the northern sector at Cap d'Es Pinar and then turned west towards Ersa (Fig. S6).

In Finokalia, both for 5 and 29 July, significant $N_{15-20}$ concentrations are also detected during the nucleation hours, but in the form of a succession of peaks that do not show the usual feature of a clear NPF event (with a continuous growth).

On 9 August, newly formed particles are detected in air masses originating from the near southern area in Ersa and from northwestern sector in Cap d'Es Pinar (see Fig. 9). The concentration of particles measured in the first SMPS size channels in Ersa $(11-15 \mathrm{~nm})$ does not present very marked variations, while $N_{15-20}$ displays more significant changes in the course of the day. These observations might suggest that, unlike previous events, NPF could not be initiated at the station itself but rather in a neighboring area (Fig. 8). Similar features are observed at Cap d'Es Pinar, with significant variations of the particle concentration in the size range $15-20 \mathrm{~nm}$, as on 29 July. The temporal evolutions of $N_{15-20}$ and $N_{20-25}$ have similar structures at both stations between 

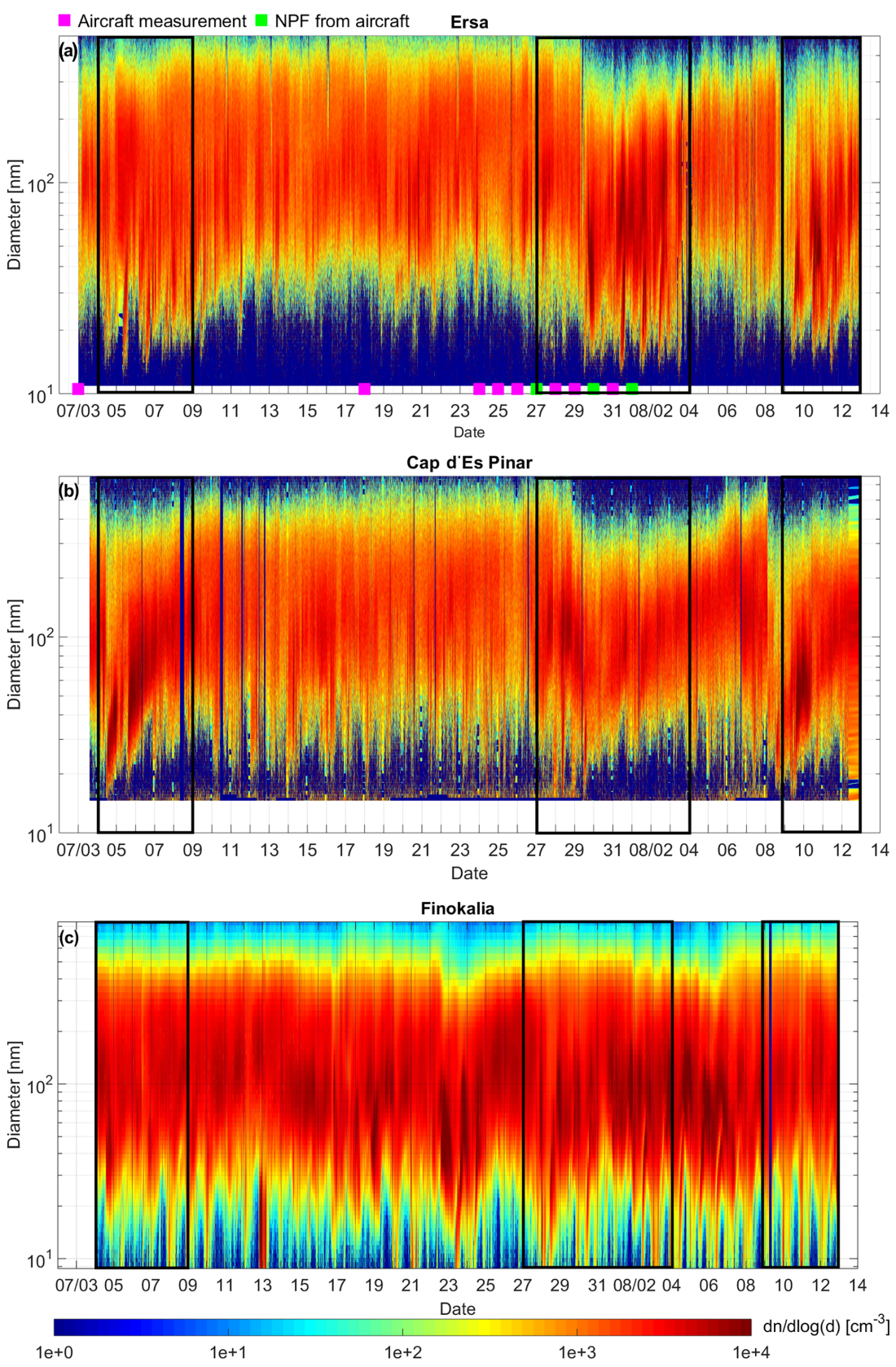

Figure 7. SMPS particle number size distribution in (a) Ersa, (b) Cap d'Es Pinar and (c) Finokalia during the SOP. The three NPF episodes observed at large scale are highlighted on the spectra in the black boxes. The days of occurrence of the ATR-42 flights are also shown, together with the detection of NPF from these airborne measurements. Same color scale applies to (a-c).

10:00 and 16:00 UTC, suggesting that NPF could occur simultaneously at both sites. Additional peaks of $N_{15-20}$ and $N_{20-25}$ are detected earlier in the morning at Cap d'Es Pinar (07:20 and 09:00 UTC), while they are not detected in Ersa. Beside the simultaneity of the process, NPF events detected at the two sites also display very similar characteristics, both regarding particle growth $\left(4.3\right.$ and $3.8 \mathrm{nmh}^{-1}$, for Ersa and Cap d'Es Pinar, respectively) and formation rates (4.83 and
$4.17 \mathrm{~cm}^{-3} \mathrm{~s}^{-1}$, for Ersa and Cap d'Es Pinar, respectively). Instrumental failure did not allow similar analysis at Finokalia.

As shown in Fig. 9 for Cap d'Es Pinar, the place where nucleation initially occurred is at least $49 \mathrm{~km}$ upstream of the station. Since all air mass back-trajectories computed during the time period of interest are very local (at least during the $24 \mathrm{~h}$ before their arrival at the site), we may hypothesize that NPF is occurring over the whole area close to Mallorca, where air mass back-trajectories overlap. Concerning Ersa, 


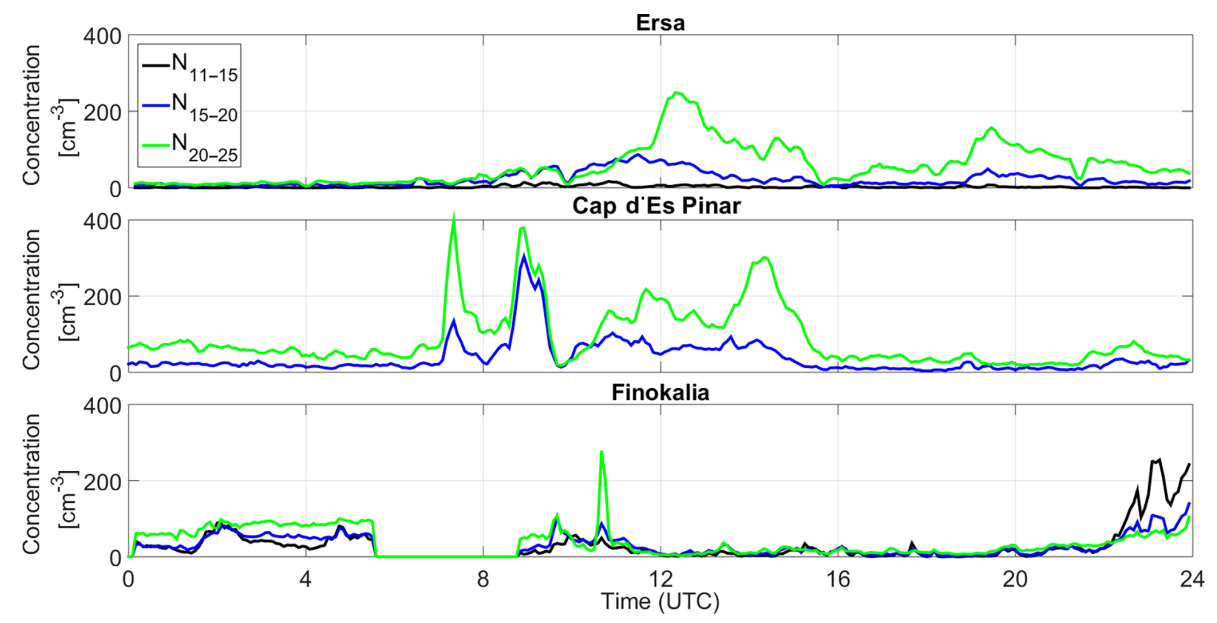

Figure 8. Temporal evolution of the particle concentrations in the size range 11-15 nm (black) $\left(N_{11-15}\right), 15-20 \mathrm{~nm}($ blue $)\left(N_{15-20}\right)$ and $20-25 \mathrm{~nm}$ (green) $\left(N_{20}-25\right)$ for 9 August event.
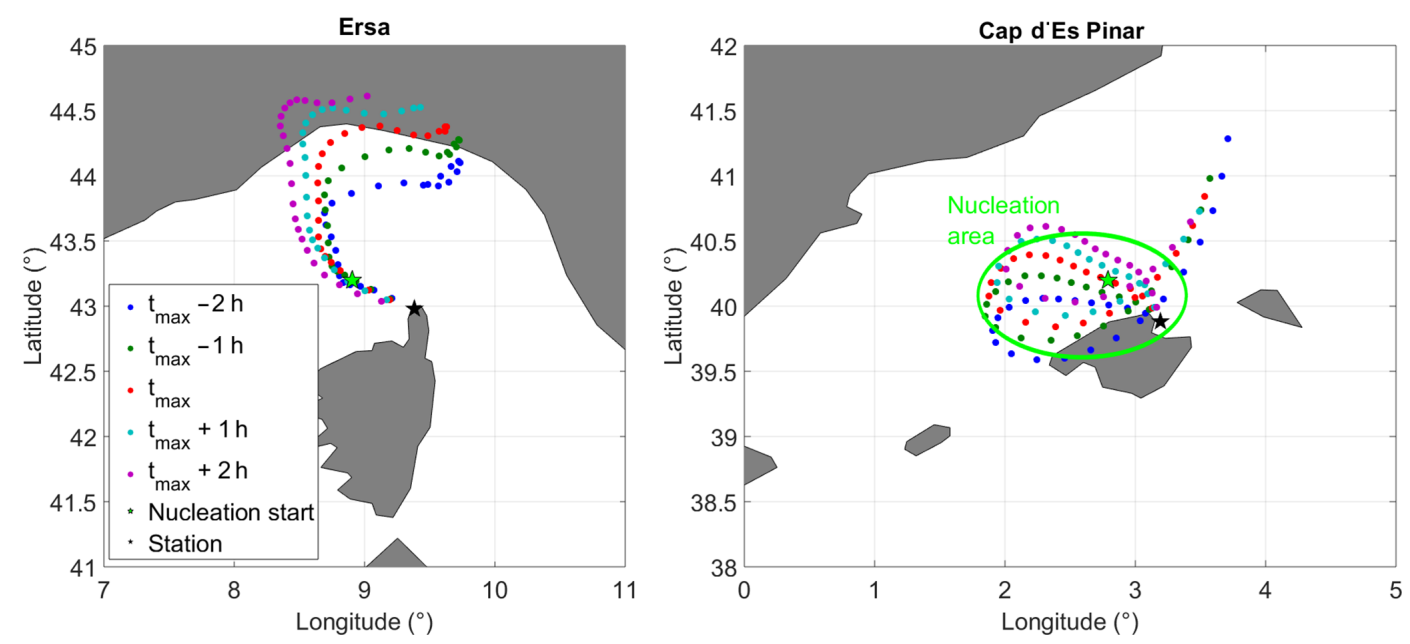

Figure 9. Back trajectories of air masses sampled in Ersa and Cap d'Es Pinar on 9 August at $t_{\max }$, when $20 \mathrm{~nm}$ particles concentration is maximum, and during the $2 \mathrm{~h}$ that precede and follow this maximum. The location where nucleation initially occurs upstream of the station is marked with a green star.

the nucleation of $20 \mathrm{~nm}$ particles later observed at the site is at least initiated $45 \mathrm{~km}$ upstream of the station.

The three case studies showed that NPF events could be detected, with some time offset, on two remote stations separated by several hundred kilometers in the Mediterranean area. In particular for the case of 9 August, the fact that these events can be detected in air masses from different origins suggest that the NPF is, for both sites, initiated above the sea, either in the marine boundary layer or higher in the free troposphere. In any case, the NPF process is likely not subject to the availability of precursors that would be specific to the air mass type reaching the sites. It could rather depend on synoptic meteorological conditions at the European scale, including low condensational sinks following precipitations periods. Indeed, the analysis of the meteorological conditions along back-trajectories shows that precipitation did occur prior to their arrival at both stations on 29 July (during the passage of low-pressure systems), but not on the two other case studies. The minimum areas that we determined for nucleation onset at both sites did not overlap. However, the estimates we obtained are some lower limits of the actual values, and there are no elements which could justify that the NPF was interrupted between both sites. Airborne measurements will be used in the next section to further investigate this aspect. In addition, these flights will allow an analysis regarding the origin of the clusters and their precursors, from the marine boundary layer or from the upper levels of the atmosphere, as previously shown by Rose et al. (2015a). 

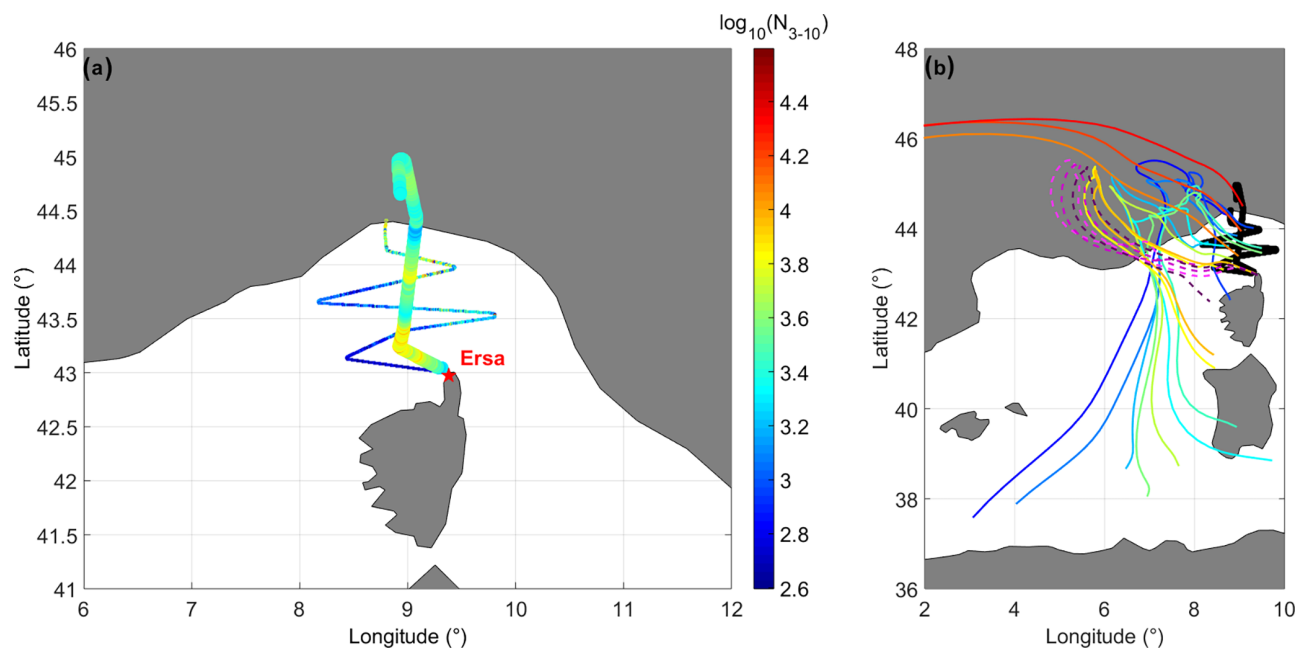

Figure 10. (a) $N_{3-10}$ above the threshold value along the flight path taken on 30 July. Large-size dots stand for high-altitude measurements ( 3400 ma.s.1.), while small-size dots stand for low-altitude measurements ( $215 \mathrm{~m}$ a.s.1.); (b) air mass back-trajectories calculated along the flight path (black line) every $10 \mathrm{~min}$ (solid colored lines) together with the back-trajectories of air masses arriving in Ersa each hour during the same time period (dashed lines).

\subsubsection{Airborne measurements}

Among the 11 flights performed during the SOP, particles in the lowest size range $\left(N_{3-10}\right)$ were not observed during 7 of the flights, in agreement with no NPF events detected at the Ersa and Cap d'Es Pinar stations. Two flights detected elevated concentrations of $N_{3-10}$ and $N_{10-20}$ in agreement with NPF events at Ersa.

The first event to be investigated was observed on 30 July. Regarding aircraft measurements, the analysis was focused on the flight legs performed at constant altitude and during which $N_{3-10}$ concentrations were above the threshold value (Fig. 10a). The first part of the flight was performed at low altitude $(\sim 215$ ma.s.l. $)$ from the French coast towards Ersa and at higher altitudes ( 3400 ma.s.l.) during the second part of the flight from Ersa towards the coast. Based on Fig. 10, small particles $\left(N_{3-10}\right)$ were detected at both altitudes and over a large area included in a $219 \mathrm{~km} \times 131 \mathrm{~km}$ rectangle. On the low-altitude flight section, $N_{3-10}$ is decreasing from the northeastern part of the flight track to the southwestern one. This would indicate a source of nanoparticles originating from the continent and progressively diluted in the marine boundary layer. However, despite a high variability, $N_{3-10}$ are on average higher at high altitude, with average concentrations of $3805 \pm 1555 \mathrm{~cm}^{-3}$ compared to $2040 \pm 2174 \mathrm{~cm}^{-3}$ at lower altitude. This last observation supports the results of Rose et al. (2015a), who reported that nucleation could be enhanced at high altitude above the Mediterranean Sea and connected to different sources at low altitude.

In order to explore the link that may exist between the events detected simultaneously from the aircraft and from the ground, we first investigated the origin of the air masses.
Figure 10b shows the $72 \mathrm{~h}$ back-trajectories of the air masses sampled by the ATR-42 every 10 min along the flight path as well as the $72 \mathrm{~h}$ back-trajectories of the air masses that reached Ersa in the meanwhile at 13:00, 14:00, and 15:00 UTC. During the first part of the flight performed at low altitude, the aircraft flew in southern air masses which all passed over the continent before sampling and became more local as the aircraft approached Ersa. In contrast, the air masses sampled at high altitude were from western origin, so that they also passed over the continent, but did not display any local features.

In addition, Fig. 11 shows the evolution of the particle size distributions measured onboard the ATR-42 and at Ersa. The spectra are color-coded according to the position of the aircraft indicated in the insert included in the middle panel of Fig. 11. At Ersa, the shape of the particle size distribution remains similar during the whole measurement period, with a nucleation mode around $20-25 \mathrm{~nm}$, an Aitken mode around $50-60 \mathrm{~nm}$ which clearly dominates the spectra and two accumulation modes, respectively around 110 and $220 \mathrm{~nm}$. These modes were identified when fitting the SMPS size distributions with four Gaussian modes using the methodology described in Rose et al. (2015a). In contrast, the size distributions provided by the SMPS onboard the ATR- 42 show significant variations. Lower concentrations are on average observed at higher altitude for the whole diameter range but with more significant changes of the nucleation and Aitken modes. The shape of the size distribution is also impacted by the location of the plane, especially at low altitude. In fact, the total particle concentration decreases as the aircraft moves further off the southern coast of France, with, again, a more visible impact on nucleation and Aitken modes. 

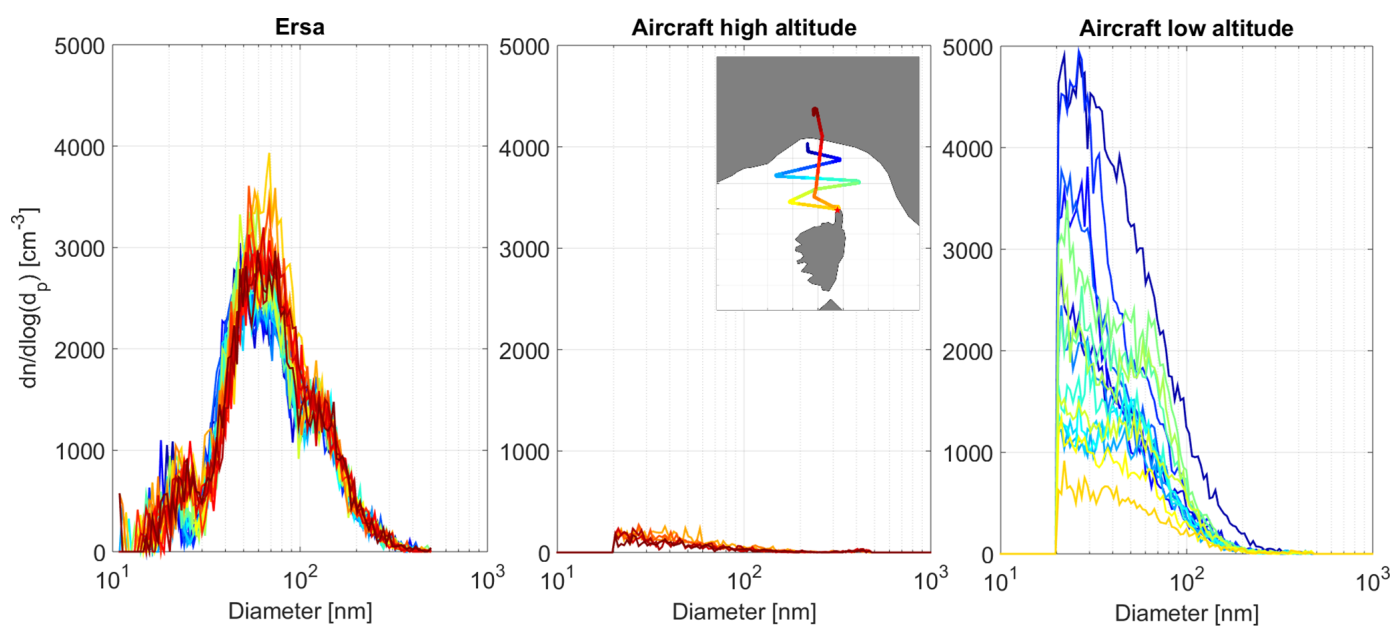

Figure 11. SMPS size distributions measured at Ersa (left panel) and onboard the ATR-42 at high altitude ( 3400 m a.s.1.) (middle panel) and low altitude ( $\sim 215 \mathrm{~m}$ a.s.1.) (right panel) on 30 July. The color coding of the size distributions corresponds to the location of the aircraft, as shown in the insert of the middle panel.

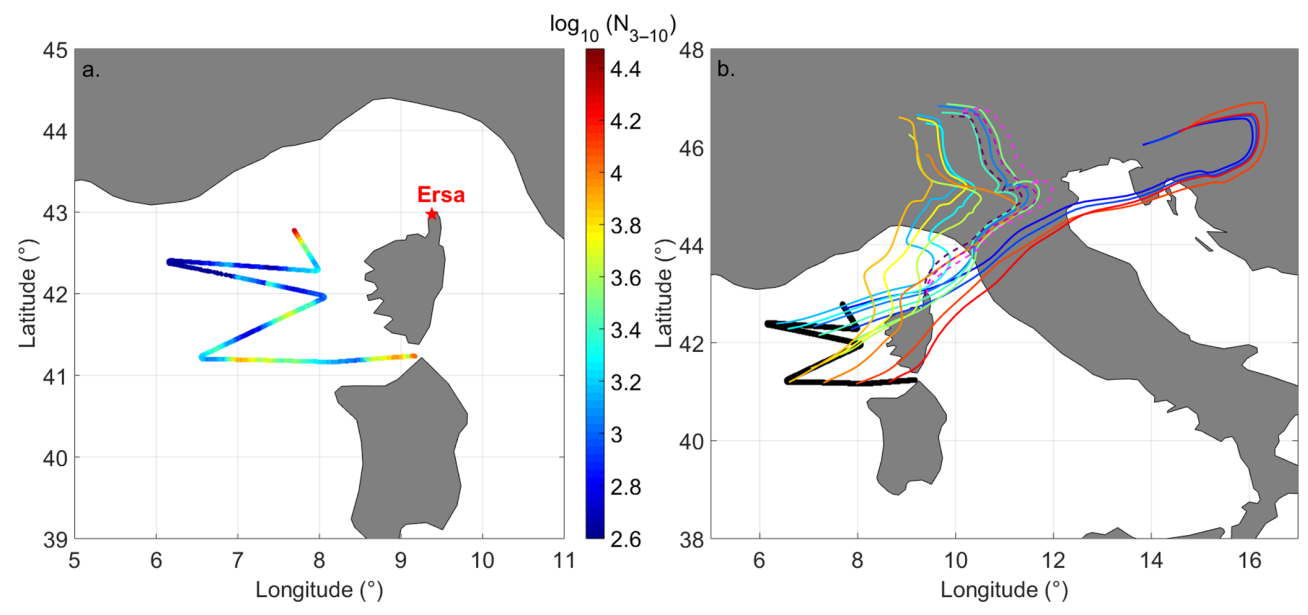

Figure 12. (a) $N_{3-10}$ above the threshold value along the flight path; (b) air mass back-trajectories (solid lines) calculated along the flight path (black line) every $10 \mathrm{~min}$ (solid colored lines) together with the back-trajectories of air masses arriving in Ersa each hour during the same time period (dashed lines) during the 1 August flight.

These last observations, together with the air mass backtrajectory analysis shown in Fig. 10b, suggest that for this first event, new particles were initially formed at low altitude over the continent and further transported above the sea to be finally detected over a large area, and more especially in Ersa. Decreasing particle concentrations observed while moving further off the continent make the hypothesis of new small particle formation from an additional marine source less probable; instead, they show the effect of dispersion process that may have taken place during particle transport.

The second event included in this analysis was observed on 1 August. Compared to the previous case study, the flight was performed over a larger area $(172 \mathrm{~km} \times 247 \mathrm{~km}$ rectangle) located further away west from Ersa and at a relatively low constant altitude $\left(\sim 500\right.$ ma.s.l.). $N_{3-10}$ concentrations above the threshold value were detected along the flight path (Fig. 12) and compared well, on average, with the concentrations obtained at low altitude during the flight performed on 30 July $\left(2483 \pm 2767 \mathrm{~cm}^{-3}\right)$. However, $N_{3-10}$ concentrations occurred as bursts, with no clear spatial gradient as previously reported for flight performed on 30 July. The analysis of air mass back-trajectories is shown in Fig. 12b. Northeastern air masses were sampled at the beginning and at the end of the flight, with northern air masses in between. Air masses from the north were also detected at Ersa and it is worth noting that, at least during the first part of the flight, the air masses that reached the aircraft had all passed over Ersa region.

The evolution of the particle size distributions together with the location of the aircraft is shown in Fig. 13. Un- 

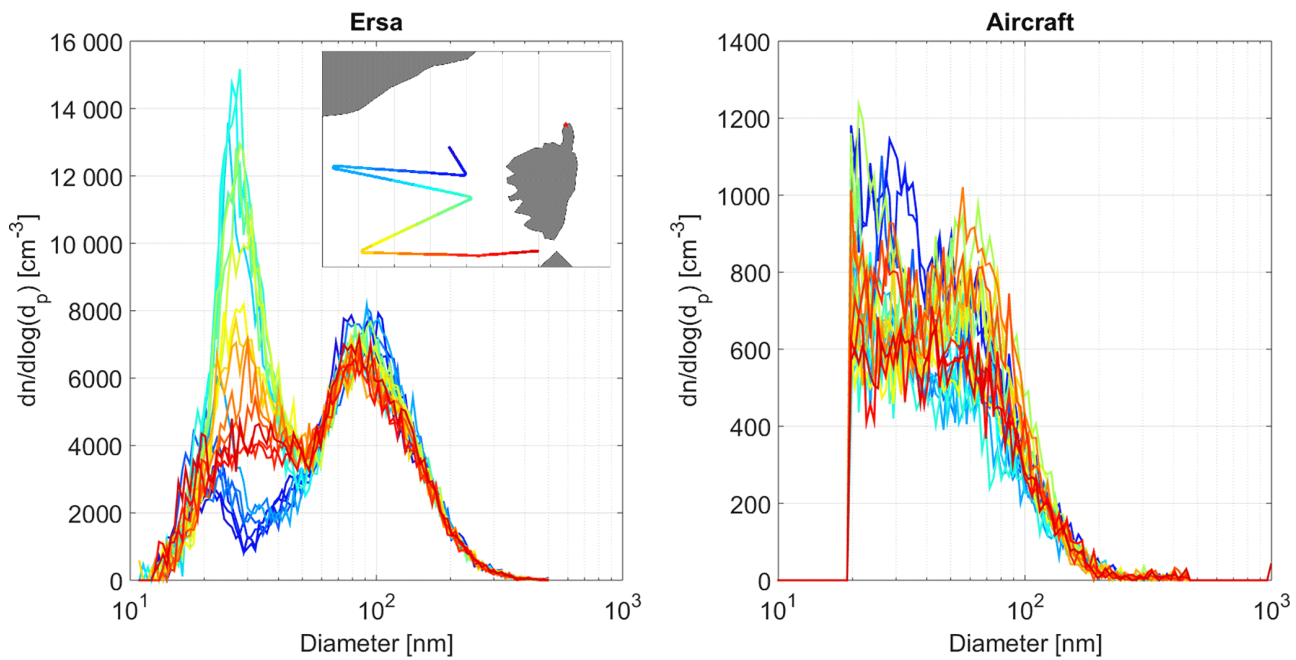

Figure 13. Ground-based (left panel) and airborne (right panel) SMPS size distributions measured on 1 August. The color coding of the spectra corresponds to the location of the aircraft, as shown on the insert of the left panel.

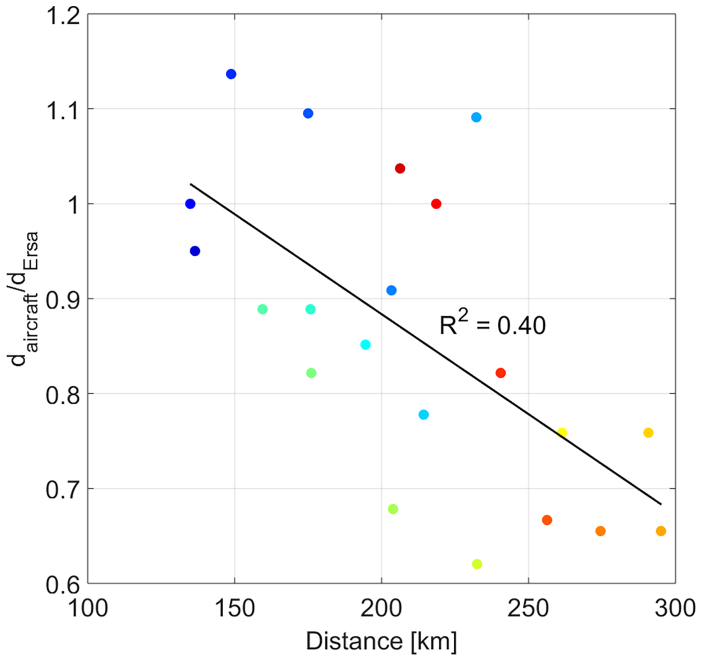

Figure 14. Ratio of nucleation-mode diameters measured onboard the ATR-42 over that calculated in Ersa as a function of the distance between the aircraft and Ersa on 1 August. The color coding of this scatter plot matches with the location of the aircraft showed in the insert of the left panel of Fig. 13.

like during the flight performed on 30 July, the shape of the distributions measured onboard the ATR-42 remains similar during the whole measurement period despite the changing origin of air masses. In contrast, the shape of the particle size distributions measured at Ersa shows significant variability. In particular, the nucleation mode displays increasing diameters from 20 to $30 \mathrm{~nm}$ and highly variable concentrations. Also, total concentrations from Ersa are significantly higher compared to those measured onboard the ATR-42.

In order to further investigate the origin of the nucleationmode particles and the connection that may exist between ground-based and airborne measurements, we compared the diameters of the corresponding nucleation modes. For that purpose, Fig. 14 shows the ratio of the nucleation-mode diameter obtained onboard the ATR-42 over that from Ersa as a function of the distance between the aircraft and the station. This ratio is in the range 0.6-1.2, with on average decreasing values while increasing the distance between the two measurement points. Nucleation-mode diameter getting smaller along the air mass back-trajectory above the sea could be the result of intense inputs of nucleated particles initially below the SMPS size detection limit and feeding the nucleation mode as they grow, as confirmed by the detection of 3-10 nm particles from the ATR-42. In this particular case, particles detected in the nucleation mode observed onboard the ATR42 would be the result of an event occurring above the sea from marine precursors, which combines with a preexisting particle mode.

\section{Conclusion}

We investigated the occurrence of NPF in the Mediterranean area using particle size distributions measured at three ground-based stations (Ersa, Cap d'Es Pinar, and Finokalia) as well as airborne measurements performed in 2013 in the frame of the CHARMEX-ADRIMED and CHARMEXSafMed projects.

The analysis of long-term datasets from Ersa and Finokalia first revealed similar features, although the two stations are more than $1000 \mathrm{~km}$ away from each other. In particular, almost equal annual NPF frequencies were reported (36 and $35 \%$, for Finokalia and Ersa, respectively) and similar seasonal variations of both the NPF frequency and characteristics, i.e., particle formation and growth rates, were observed. The NPF process was on average favored during spring, both 
in terms of occurrence and intensity, most probably because of increased amounts of precursors from biogenic origin and higher solar radiation, thus allowing for more efficient photochemistry processes.

This investigation, initially performed at a monthly resolution, was downscaled in a second step at the daily resolution over a two months period, in order to further assess the simultaneity of NPF over a large part of the Mediterranean Basin. Three simultaneous nucleation periods of several days appeared clearly for Ersa and Cap d'Es Pinar, and less clearly at Finokalia. NPF formation was observed to occur simultaneously at least at two of the three stations on 8 days over the 41 days of observation, which confirms the frequent occurrence of regional-scale NPF events in the Mediterranean area. Three case study events were selected within these three distinct NPF periods for a more detailed analysis. These three case studies showed that NPF events could be detected, with some time offset, on two remote stations separated by several hundred kilometers in the Mediterranean Basin, without the stations being directly linked to each other within a single air mass trajectory. While featuring local characteristics, the occurrence of NPF events was likely not dependant on the availability of precursors that would be specific to the air mass type reaching the sites, but rather on synoptic meteorological conditions at the European scale. Komppula et al. (2006) also concluded from observation from two different sites $250 \mathrm{~km}$ apart, that the occurrence of NPF in a certain air mass type depended not only on the local conditions promoting the process (such as photochemistry) but also on some properties carried by the air mass itself. Likewise, Hussein et al. (2009) showed from a multi-site observations dataset in Scandinavia that although large-spatial-scale NPF events were observed simultaneously between several stations, their characteristics usually differ in term of temporal evolution, due to different local meteorological conditions, and maybe variable local emissions.

The case studies also showed that despite the fact that nucleation monthly frequencies, monthly nucleation rates, and growth rates had similar seasonal variations in Ersa and Finokalia, different behaviors were observed on a daily basis between the western and eastern Mediterranean basins. Again, the combination of favorable synoptic conditions and seasonal variations in general emission schemes may favor a seasonal behavior of the NPF frequency and characteristics, but local conditions are modulating the general behavior of regional NPF.

Airborne measurements were finally used to further investigate the horizontal and vertical extent of NPF, as well as to determine the origin of the clusters and their precursors. Two case studies were again selected within the NPF periods identified previously from ground-based observations, during which newly formed clusters were observed onboard the ATR-42 and from Ersa on the same day. Airborne measurements confirmed the regional spatial extent of NPF events, and further showed regional NPF events can have differ- ent sources. The selected events depicted contrasting situations where particles were initially probably formed above the continent for one of them, both in the boundary layer and in the free troposphere, and probably formed above the sea for the other.

This work, together with the previous study by Rose et al. (2015a), demonstrates the occurrence of NPF in the Mediterranean Basin, thus highlighting the possibility for the process to be triggered above open seas. These results are of great interest to improve the parameterizations of nucleation in models, which actually only consider a limited number of precursors, commonly including sulfuric acid and ammonia but excluding those more specifically emitted in the marine atmosphere. Model predictions would also benefit from the analysis of the vertical extent of the NPF process provided in these studies. Besides the identification of preferential altitudes for the occurrence of the process, these results aid in understanding the transport of the newly formed clusters and their precursors between the boundary layer and the free troposphere. Future studies should focus on understanding the chemical precursors that contribute to these new particle formation processes.

Data availability. SMPS data from ERSA and Cap d'Es Pinar are available at http://mistrals.sedoo.fr/ChArMEx.

\section{The Supplement related to this article is available online at https://doi.org/10.5194/acp-17-9567-2017-supplement.}

Competing interests. The authors declare that they have no conflict of interest.

Special issue statement. This article is part of the special issue "CHemistry and AeRosols Mediterranean EXperiments (ChArMEx) (ACP/AMT inter-journal SI)". It is not associated with a conference.

Acknowledgements. This study was performed with the financial support of the French National Research Agency (ANR) project ADRIMED (contract ANR-11-BS56-0006) the ANR project "SAf-Med" (grant number: SIMI-5-6 022 04) and is part of the ChArMEx project supported by ADEME, CEA, CNRS-INSU, and Météo-France through the multidisciplinary programme MISTRALS (Mediterranean Integrated Studies aT Regional And Local Scales). The financial support for the ACTRIS Research Infrastructure Project by the European Union's Horizon 2020 research and innovation program under grant agreement no. 654169 and previously under grant agreement no. 262254 in the 7th Framework Programme (FP7/2007-2013) is gratefully acknowledged. 
Edited by: Evangelos Gerasopoulos

Reviewed by: two anonymous referees

\section{References}

Birmili, W., Berresheim, H., Plass-Dülmer, C., Elste, T., Gilge, S., Wiedensohler, A., and Uhrner, U.: The Hohenpeissenberg aerosol formation experiment (HAFEX): a long-term study including size-resolved aerosol, $\mathrm{H}_{2} \mathrm{SO}_{4}, \mathrm{OH}$, and monoterpenes measurements, Atmos. Chem. Phys., 3, 361-376, https://doi.org/10.5194/acp-3-361-2003, 2003.

Crippa, P. and Pryor, S. C.: Spatial and temporal scales of new particle formation events in eastern North America, Atmos. Environ., 75, 257-264, https://doi.org/10.1016/j.atmosenv.2013.04.051, 2013.

Crumeyrolle, S., Manninen, H. E., Sellegri, K., Roberts, G., Gomes, L., Kulmala, M., Weigel, R., Laj, P., and Schwarzenboeck, A.: New particle formation events measured on board the ATR-42 aircraft during the EUCAARI campaign, Atmos. Chem. Phys., 10, 6721-6735, https://doi.org/10.5194/acp-106721-2010, 2010.

Cusack, M., Pérez, N., Pey, J., Alastuey, A., and Querol, X.: Source apportionment of fine PM and sub-micron particle number concentrations at a regional background site in the western Mediterranean: a 2.5 year study, Atmos. Chem. Phys., 13, 5173-5187, https://doi.org/10.5194/acp-13-5173-2013, 2013.

Dall'Osto, M., Querol, X., Alastuey, A., O’Dowd, C., Harrison, R. M., Wenger, J., and Gómez-Moreno, F. J.: On the spatial distribution and evolution of ultrafine particles in Barcelona, Atmos. Chem. Phys., 13, 741-759, https://doi.org/10.5194/acp13-741-2013, 2013.

Dal Maso, M., Kulmala, M., Riipinen, I., Wagner, R., Hussein, T., Aalto, P. P., and Lehtinen, K. E. J.: Formation and growth of fresh atmospheric aerosols: eight years of aerosol size distribution data from SMEAR II, Hyytiälä, Finland, Boreal Environ. Res., 10, 323-336, 2005.

Draxler, R. R. and Rolph, G. D.: HYSPLIT (Hybrid Single-Particle Langrangian Integrated Trajectory) Model access via NOAA ARL READY website, available at: http://www.arl.noaa.gov/ ready/hysplit4.html (last access: September 2014), 2003.

Hamed, A., Birmili, W., Joutsensaari, J., Mikkonen, S., Asmi, A., Wehner, B., Spindler, G., Jaatinen, A., Wiedensohler, A., Korhonen, H., Lehtinen, K. E. J., and Laaksonen, A.: Changes in the production rate of secondary aerosol particles in Central Europe in view of decreasing $\mathrm{SO}_{2}$ emissions between 1996 and 2006, Atmos. Chem. Phys., 10, 1071-1091, https://doi.org/10.5194/acp-10-1071-2010, 2010.

Hirsikko, A., Laakso, L., Hörrak, U., Aalto, P. P., Kerminen, V.M., and Kulmala, M.: Annual and size dependent variation of growth rates and ion concentrations in boreal forest, Boreal Environ. Res., 10, 357-369, 2005.

Hirsikko, A., Bergman, T., Laakso, L., Dal Maso, M., Riipinen, I., Hõrrak, U., and Kulmala, M.: Identification and classification of the formation of intermediate ions measured in boreal forest, Atmos. Chem. Phys., 7, 201-210, https://doi.org/10.5194/acp-7201-2007, 2007.
Hussein, T., Junninen, H., Tunved, P., Kristensson, A., Dal Maso, M., Riipinen, I., Aalto, P. P., Hansson, H.-C., Swietlicki, E., and Kulmala, M.: Time span and spatial scale of regional new particle formation events over Finland and Southern Sweden, Atmos. Chem. Phys., 9, 4699-4716, https://doi.org/10.5194/acp-9-4699-2009, 2009.

Jeong, C.-H., Hopke, P. K., Chalupa, D., and Utell, M.: Characteristics of nucleation and growth events of ultrafine particles measured in Rochester, NY, Environ. Sci. Technol., 38, 1933-1940, https://doi.org/10.1021/es034811p, 2004.

Kalivitis, N., Birmili, W., Stock, M., Wehner, B., Massling, A., Wiedensohler, A., Gerasopoulos, E., and Mihalopoulos, N.: Particle size distributions in the Eastern Mediterranean troposphere, Atmos. Chem. Phys., 8, 6729-6738, https://doi.org/10.5194/acp8-6729-2008, 2008.

Kalivitis, N., Stavroulas, I., Bougiatioti, A., Kouvarakis, G., Gagné, S., Manninen, H. E., Kulmala, M., and Mihalopoulos, N.: Night-time enhanced atmospheric ion concentrations in the marine boundary layer, Atmos. Chem. Phys., 12, 3627-3638, https://doi.org/10.5194/acp-12-3627-2012, 2012.

Kalivitis, N., Kerminen, V.-M., Kouvarakis, G., Stavroulas, I., Bougiatioti, A., Nenes, A., Manninen, H. E., Petäjä, T., Kulmala, M., and Mihalopoulos, N.: Atmospheric new particle formation as a source of $\mathrm{CCN}$ in the eastern Mediterranean marine boundary layer, Atmos. Chem. Phys., 15, 9203-9215, https://doi.org/10.5194/acp-15-9203-2015, 2015.

Kim, Y., Kim, S.-W., Yoon, S.-C., Park, J.-S., Lim, J.-H., Hong, J., Lim, H.-C., Ryu, J., Lee, C.-K., and Heo, B.-H.: Characteristics of formation and growth of atmospheric nanoparticles observed at four regional background sites in Korea, Atmos. Res., 168, 80-91, doi.org/10.1016/j.atmosres.2015.08.020, 2016.

Komppula, M., Sihto, S.-L., Korhonen, H., Lihavainen, H., Kerminen, V.-M., Kulmala, M., and Viisanen, Y.: New particle formation in air mass transported between two measurement sites in Northern Finland, Atmos. Chem. Phys., 6, 2811-2824, https://doi.org/10.5194/acp-6-2811-2006, 2006.

Koren, I., Dagan, G., and Altaratz, O.: From aerosol-limited to invigoration of warm convective clouds, Science, 344, 1143-1146, 2014.

Kouvarakis, G., Tsigaridis, K., Kanakidou, M., and Mihalopoulos, N.: Temporal variations of surface regional background ozone over Crete Island in the southeast Mediterranean, J. Geophys. Res.-Atmos., 105, 4399-4407, 2000.

Kristensson, A., Johansson, M., Swietlicki, E., Kivekäs, N., Hussein, T., Nieminen, T., Kulmala, M., and Dal Maso, M.: NanoMap: geographical mapping of atmospheric new particle formation through analysis of 1 particle number size distribution data available at: http://www.cast.lu.se/Kristensson\%20\%20NanoMap\%20paper\%20v4.pdf (last access: 14 March 2016), 2014.

Kulmala, M., Vehkamäki, H., Petäjä, T., Dal Maso, M., Lauri, A., Kerminen, V.-M., Birmili, W., and McMurry, P. H.: Formation and growth rates of ultrafine atmospheric particles: a review of observations, J. Aerosol Sci., 35, 143-176, 2004.

Kulmala, M., Petäjä, T., Mönkkönen, P., Koponen, I. K., Dal Maso, M., Aalto, P. P., Lehtinen, K. E. J., and Kerminen, V.M.: On the growth of nucleation mode particles: source rates of condensable vapor in polluted and clean environments, At- 
mos. Chem. Phys., 5, 409-416, https://doi.org/10.5194/acp-5409-2005, 2005.

Lambert, D., Mallet, M., Ducrocq, V., Dulac, F., Gheusi, F., and Kalthoff, N.: CORSiCA: a Mediterranean atmospheric and oceanographic observatory in Corsica within the framework of HyMeX and ChArMEx, Adv. Geosci., 26, 125-131, 2011.

Makkonen, R., Asmi, A., Kerminen, V.-M., Boy, M., Arneth, A., Hari, P., and Kulmala, M.: Air pollution control and decreasing new particle formation lead to strong climate warming, Atmos. Chem. Phys., 12, 1515-1524, https://doi.org/10.5194/acp12-1515-2012, 2012.

Mallet, M., Dulac, F., Formenti, P., Nabat, P., Sciare, J., Roberts, G., Pelon, J., Ancellet, G., Tanré, D., Parol, F., Denjean, C., Brogniez, G., di Sarra, A., Alados-Arboledas, L., Arndt, J., Auriol, F., Blarel, L., Bourrianne, T., Chazette, P., Chevaillier, S., Claeys, M., D’Anna, B., Derimian, Y., Desboeufs, K., Di Iorio, T., Doussin, J.-F., Durand, P., Féron, A., Freney, E., Gaimoz, C., Goloub, P., Gómez-Amo, J. L., Granados-Muñoz, M. J., Grand, N., Hamonou, E., Jankowiak, I., Jeannot, M., Léon, J.-F., Maillé, M., Mailler, S., Meloni, D., Menut, L., Momboisse, G., Nicolas, J., Podvin, T., Pont, V., Rea, G., Renard, J.-B., Roblou, L., Schepanski, K., Schwarzenboeck, A., Sellegri, K., Sicard, M., Solmon, F., Somot, S., Torres, B., Totems, J., Triquet, S., Verdier, N., Verwaerde, C., Waquet, F., Wenger, J., and Zapf, P.: Overview of the ChemistryAerosol Mediterranean Experiment/Aerosol Direct Radiative Forcing on the Mediterranean Climate (ChArMEx/ADRIMED) summer 2013 campaign, Atmos. Chem. Phys., 16, 455-504, https://doi.org/10.5194/acp-16-455-2016, 2016.

Manninen, H. E., Nieminen, T., Asmi, E., Gagné, S., Häkkinen, S., Lehtipalo, K., Aalto, P., Vana, M., Mirme, A., Mirme, S., Hõrrak, U., Plass-Dülmer, C., Stange, G., Kiss, G., Hoffer, A., Törő, N., Moerman, M., Henzing, B., de Leeuw, G., Brinkenberg, M., Kouvarakis, G. N., Bougiatioti, A., Mihalopoulos, N., O’Dowd, C., Ceburnis, D., Arneth, A., Svenningsson, B., Swietlicki, E., Tarozzi, L., Decesari, S., Facchini, M. C., Birmili, W., Sonntag, A., Wiedensohler, A., Boulon, J., Sellegri, K., Laj, P., Gysel, M., Bukowiecki, N., Weingartner, E., Wehrle, G., Laaksonen, A., Hamed, A., Joutsensaari, J., Petäjä, T., Kerminen, V.-M., and Kulmala, M.: EUCAARI ion spectrometer measurements at 12 European sites - analysis of new particle formation events, Atmos. Chem. Phys., 10, 7907-7927, https://doi.org/10.5194/acp10-7907-2010, 2010.

Merikanto, J., Spracklen, D. V., Mann, G. W., Pickering, S. J., and Carslaw, K. S.: Impact of nucleation on global CCN, Atmos. Chem. Phys., 9, 8601-8616, https://doi.org/10.5194/acp-9-86012009, 2009.

Mihalopoulos, N., Stephanou, E., Kanakidou, M., Pilitsidis, S., and Bousquet, P.: Tropospheric aerosol ionic composition in the Eastern Mediterranean region, Tellus B, 49, 314-326, 1997.

Nabat, P., Somot, S., Mallet, M., Chiapello, I., Morcrette, J. J., Solmon, F., Szopa, S., Dulac, F., Collins, W., Ghan, S., Horowitz, L. W., Lamarque, J. F., Lee, Y. H., Naik, V., Nagashima, T., Shindell, D., and Skeie, R.: A 4-D climatology (1979-2009) of the monthly tropospheric aerosol optical depth distribution over the Mediterranean region from a comparative evaluation and blending of remote sensing and model products, Atmos. Meas. Tech., 6, 1287-1314, https://doi.org/10.5194/amt6-1287-2013, 2013.
Pey, J., Rodríguez, S., Querol, X., Alastuey, A., Moreno, T., Putaud, J. P., and Van Dingenen, R.: Variations of urban aerosols in the western Mediterranean, Atmos. Environ., 42, 9052-9062, https://doi.org/10.1016/j.atmosenv.2008.09.049, 2008.

Pikridas, M., Bougiatioti, A., Hildebrandt, L., Engelhart, G. J., Kostenidou, E., Mohr, C., Prévôt, A. S. H., Kouvarakis, G., Zarmpas, P., Burkhart, J. F., Lee, B.-H., Psichoudaki, M., Mihalopoulos, N., Pilinis, C., Stohl, A., Baltensperger, U., Kulmala, M., and Pandis, S. N.: The Finokalia Aerosol Measurement Experiment - 2008 (FAME-08): an overview, Atmos. Chem. Phys., 10, 6793-6806, https://doi.org/10.5194/acp-106793-2010, 2010.

Pikridas, M., Riipinen, I., Hildebrandt, L., Kostenidou, E., Manninen, H., Mihalopoulos, N., Kalivitis, N., Burkhart, J. F., Stohl, A., Kulmala, M., and Pandis, S. N.: New particle formation at a remote site in the eastern Mediterranean, J. Geophys. Res.-Atmos. 117, D12205, https://doi.org/10.1029/2012JD017570, 2012.

Pirjola, L., Kulmala, M., Wilck, M., Bischoff, A., Stratmann, F., and Otto, E.: Formation of sulphuric acid aerosols and cloud condensation nuclei: an expression for significant nucleation and model comparison, J. Aerosol Sci., 30, 1079-1094, https://doi.org/10.1016/S0021-8502(98)00776-9, 1999.

Rose, C., Sellegri, K., Freney, E., Dupuy, R., Colomb, A., Pichon, J.-M., Ribeiro, M., Bourianne, T., Burnet, F., and Schwarzenboeck, A.: Airborne measurements of new particle formation in the free troposphere above the Mediterranean Sea during the HYMEX campaign, Atmos. Chem. Phys., 15, 1020310218, https://doi.org/10.5194/acp-15-10203-2015, 2015a.

Rose, C., Sellegri, K,, Velarde, F., Moreno, I., Ramonet, M., Weinhold, K., Krejci, R., Andrade, M., Wiedensohler, A., and Laj, P.: Multiple daytime nucleation events at the high altitude station of Chacaltaya (5240 ma.s.1.), Bolivia, Atmos. Environ., 102, 18 29, https://doi.org/10.1016/j.atmosenv.2014.11.015, 2015b.

Rosenfeld, D., Sherwood, S., Wood, R., and Donner, L.: Climate effects of aerosol-cloud interactions, Science, 343, 379-380, https://doi.org/10.1126/science.1247490, 2014.

Sihto, S.-L., Kulmala, M., Kerminen, V.-M., Dal Maso, M., Petäjä, T., Riipinen, I., Korhonen, H., Arnold, F., Janson, R., Boy, M., Laaksonen, A., and Lehtinen, K. E. J.: Atmospheric sulphuric acid and aerosol formation: implications from atmospheric measurements for nucleation and early growth mechanisms, Atmos. Chem. Phys., 6, 4079-4091, https://doi.org/10.5194/acp-6-40792006, 2006.

Sciare, J., Oikonomou, K., Favez, O., Liakakou, E., Markaki, Z., Cachier, H., and Mihalopoulos, N.: Long-term measurements of carbonaceous aerosols in the Eastern Mediterranean: evidence of long-range transport of biomass burning, Atmos. Chem. Phys., 8, 5551-5563, https://doi.org/10.5194/acp-8-5551-2008, 2008.

Spracklen, D. V., Carslaw, K. S., Kulmala, M., Kerminen, V.-M., Sihto, S.-L., Riipinen, I., Merikanto, J., Mann, G. W., Chipperfield, M. P., Wiedensohler, A., Birmili, W., and Lihavainen, H.: Contribution of particle formation to global cloud condensation nuclei concentrations, Geophys. Res. Lett., 35, L06808, https://doi.org/10.1029/2007GL033038, 2008.

Tao, W.-K., Chen, J.-P., Li, Z., Wang, C., and Zhang, C.: Impact of aerosols on convective clouds and precipitation, Rev. Geophys., 50, RG2001, https://doi.org/10.1029/2011RG000369, 2012.

Vana, M., Kulmala, M., Dal Maso, M., Hõrrak, U., and Tammet, E.: Comparative study of nucleation mode aerosol particles and 
intermediate air ions formation events at three sites, J. Geophys. Res., 109, D17201, https://doi.org/10.1029/2003JD004413, 2004.

Weigel, R., Hermann, M., Curtius, J., Voigt, C., Walter, S., Böttger, T., Lepukhov, B., Belyaev, G., and Borrmann, S.: Experimental characterization of the COndensation PArticle counting System for high altitude aircraft-borne application, Atmos. Meas. Tech., 2, 243-258, https://doi.org/10.5194/amt-2243-2009, 2009.

Wiedensohler, A., Birmili, W., Nowak, A., Sonntag, A., Weinhold, K., Merkel, M., Wehner, B., Tuch, T., Pfeifer, S., Fiebig, M., Fjäraa, A. M., Asmi, E., Sellegri, K., Depuy, R., Venzac, H., Villani, P., Laj, P., Aalto, P., Ogren, J. A., Swietlicki, E., Williams, P., Roldin, P., Quincey, P., Hüglin, C., FierzSchmidhauser, R., Gysel, M., Weingartner, E., Riccobono, F., Santos, S., Grüning, C., Faloon, K., Beddows, D., Harrison, R., Monahan, C., Jennings, S. G., O'Dowd, C. D., Marinoni, A., Horn, H.-G., Keck, L., Jiang, J., Scheckman, J., McMurry, P. H., Deng, Z., Zhao, C. S., Moerman, M., Henzing, B., de Leeuw, G., Löschau, G., and Bastian, S.: Mobility particle size spectrometers: harmonization of technical standards and data structure to facilitate high quality long-term observations of atmospheric particle number size distributions, Atmos. Meas. Tech., 5, 657-685, https://doi.org/10.5194/amt-5-657-2012, 2012.
Yli-Juuti, T., Riipinen, I., Aalto, P. P., Nieminen, T., Maenhaut, W., Janssens, I. A., Claeys, M., Salma, I., Ocskay, R., and Hoffer, A.: Characteristics of new particle formation events and cluster ions at K-puszta, Hungary, Boreal Environ. Res., 14, 683-698, 2009.

Yli-Juuti, T., Nieminen, T., Hirsikko, A., Aalto, P. P., Asmi, E., Hõrrak, U., Manninen, H. E., Patokoski, J., Dal Maso, M., Petäjä, T., Rinne, J., Kulmala, M., and Riipinen, I.: Growth rates of nucleation mode particles in Hyytiälä during 20032009: variation with particle size, season, data analysis method and ambient conditions, Atmos. Chem. Phys., 11, 12865-12886, https://doi.org/10.5194/acp-11-12865-2011, 2011.

Young, L.-H., Benson, D. R., Montanaro, W. M., Lee, S.-H., Pan, L. L., Rogers, D. C., Jensen, J., Stith, J. L., Davis, C. A., Campos, T. L., Bowman, K. P., Cooper, W. A., and Lait, L. R.: Enhanced new particle formation observed in the northern midlatitude tropopause region, J. Geophys. Res., 112, D10218, https://doi.org/10.1029/2006JD008109, 2007. 